\title{
Liminal Spaces and the Transgender Experience
}

\section{Dianne Dentice ${ }^{1}$ and Michelle Dietert ${ }^{2}$}

Transgender individuals are people whose gender identity and/or gender expression does not converge with gender norms associated with assigned sex at birth. A sub-category of people who identify as genderqueer are exploring gender expression along a continuum beyond the confines of traditional binary definitions of either male or female. We suggest that individuals who undergo some form of physical transformation may experience a temporary liminal state as they transition from one gender identity to the other. Others who fall under the transgender umbrella but are not transsexual may not fully transition but rather remain somewhere in-between the binary categories of female or male. This phenomenon illustrates the transient and complex nature of gender identity formation. Our study explores the many ways that transgender individuals and people who identify with the transgender community are managing their journey and negotiating their identities. Interviews with 21 people in various stages of transformation/transition demonstrate that coming to grips with one's true gender identity is reinforced by ritual experiences along with the support of friends, family, and other social networks. [Article copies available for a fee from The Transformative Studies Institute. E-mail address: journal@transformativestudies.org http://www.transformativestudies.org (C2015 by The Transformative Studies Institute. All rights reserved.]

KEYWORDS: Transgender, Gender Identity, Gender Expression, Sexual Diversity, Liminality.

\footnotetext{
${ }^{1}$ Dianne Dentice received her Ph.D. in Sociology from Texas Woman's University in 2006. Her teaching specializations include race and ethnic relations and gender. Her research interests include extremist religions, extremist social movements in the U.S., and gender inequality issues. Address correspondence to: Dianne Dentice, Stephen F. Austin State University, 1956 North Street, SFA Station, Nacogdoches, Texas, 75962-3047; email: denticede@sfasu.edu.

${ }^{2}$ Michelle Dietert received her Ph.D. in Sociology from Texas Woman's University in 2008. Her teaching specializations include gender and military family life. Her research interests include the transgender experience in U.S. society.
} 